\title{
Towards an Ahistorical Jewishness : The Idea of Jewish \\ Essence in German-Jewish Avant-Garde
}

\section{Sjöberg, Sami}

de Gruyter

2017

Sjöberg , S 2017 , Towards an Ahistorical Jewishness : The Idea of Jewish Essence in German-Jewish Avant-Garde . in M H Gelber \& S Sjöberg (eds), Jewish Aspects in Avant-Garde : Between Rebellion and Revelation. Perspectives on Jewish Texts and Contexts , no. 5 , de Gruyter , pp. 53-67 . https://doi.org/10.1515/9783110454956-005

http://hdl.handle.net/10138/312011

https://doi.org/10.1515/9783110454956-005

unspecified

acceptedVersion

Downloaded from Helda, University of Helsinki institutional repository.

This is an electronic reprint of the original article.

This reprint may differ from the original in pagination and typographic detail.

Please cite the original version. 


\section{Towards an Ahistorical Jewishness. The Idea of Jewish Essence in the German-Jewish Avant-Garde}

Es ist Frühling im Abendlande. Die Dichtung mit zwei Gesichtern singt Untergang und Aufgang. Vielleicht verkündet sich hier eine

Vereinung von Orient und Occident. ${ }^{1}$

The idea of a "Jewish essence" (Jüdisches Wesen), denoting a particular and recognizable Jewish quality or mode of being, was a controversial issue in early-twentieth-century cultural debates in Germany. The concept was originally devised in order to write the first accounts of "Jewish history," providing the necessary continuity for such narratives. In the sense applied in this essay, the notion surfaced during the fin-de-siècle era and survived well into the 1930s, with similar notional inquiries being topical even today.

The expressionist author Alfred Wolfenstein (1883-1945) wrote several pieces about the relation between Jews and the so-called "new poetry," which in the German-speaking world refers to the avantgarde. The image "Die Zeit der Übergänge verstärkt ibr Gewimmel auf allen Brücken" [The time of transitions causes a rush on all bridges] begins many an essay that Wolfenstein $(1922 \mathrm{~b}, 428)$ devoted to the topic. ${ }^{2}$ He envisioned a Jew, whose status is all but certain, standing in the middle of some congestion. In Wolfenstein's metaphor the old shore belongs not to the Jew, and neither yet does the bridge; instead, the "Bewegung darüberbin ist sein Schicksal und das Kommende winkt ibm so gut wie den andern" [movement from there is his fate and the Coming already beckons him just like the others] (Wolfenstein 1922, 428). The future thus holds a promise of equality with these others, here denoting the mainstream German population, which is inscribed in the portentous fate of the Jew. For Wolfenstein, being Jewish signifies striving towards the future, with the subtextual promise that this future is preferable to the current moment, and it was this striving he grasped as the very "essence" of Jewishness.

Wolfenstein's emphasis on the future echoes the avant-garde, which is by definition forward-looking. He recognized this similarity, and the avant-garde had an instrumental role in the future he had predicted. Arguably, for him, the avant-garde was an essential method in the eventual overcoming of the distinction between the German and German-Jewish populations - as is evident in the epigraph of

\footnotetext{
1 "Spring has arrived in the West. Poetry with two aspects [i.e., Jewish and German] sings of decline and emergence. Perhaps a union between the Orient and Occident is being heralded." Wolfenstein 1922a, 357. All translations are by the author unless otherwise indicated.

${ }^{2}$ Wolfenstein's works on the topic include Jüdisches Wesen und neue Dichtung (1922), "Das neue Dichtertum des Juden" (1922), "Jüdisches Wesen und Dichtertum" (1922), "Von der Dichtung des Juden" (1934) and "Vom deutschjüdischen Dichter der Gegenwart” (1935-1936).
} 
this essay. However, his aim was not to identify the avant-garde with Judaism in any traditional sense of the latter term, but rather to fashion it into a common groundwork for modern Jews and Germans.

Hence, Wolfenstein's understanding of "Jewish essence" was disconnected from such orthodoxtheological definitions of Jewishness that derived from Judaism, that is, religion. Indeed, Wolfenstein (1993a [1936], 402) regarded the avant-garde as an emancipation from Jewish history, or what he called "our false selves." Therefore, the key question his stance raises is how did German-Jewish artists who were active in the avant-garde understand the idea and contexts of a Jewish essence? What kinds of traditional and modern connotations did it have, and how did they link with contemporary attitudes towards religion and secularism? Moreover, how did it affect these artists' work? Given the emphasis of the epigraph above, the framework for this inquiry is decidedly esthetic. In Wolfenstein's case, unlike most characterizations contemporary to his, there is no direct causality between the ethnic origin of the artist and any possible "Jewishness" of his or her work. Yet, in the context of the avant-garde, it seems that in addition to explicit characteristics there is also an implicit "Jewish" quality to the works of the artists whom Wolfenstein addresses: this quality derives not only from the theme of the works but from the way things are seen and how their intrinsic values are displayed.

Wolfenstein (1993b [1935-1936], 215) regarded poetry as the most immediate form of art, due to its medium: words required no recoding into other media. The present essay will thus delve into Wolfenstein's poetics and politics of "amalgamation" by examining the German-Jewish background from which his ideas emerged. The mapping of the modern usage of "Jewish essence" illuminates the latter part of the inquiry, which focuses on the relation between Judaism and the avant-garde, and especially on the futurospective emphasis of Wolfenstein's interpretation of "Jewish essence" and how its religious content is appropriated to esthetics.

\section{Debates regarding Jewish essence}

Wolfenstein explains that the "Jewish essence" is found exclusively in the German language. According to him, there remains no trace of it in the Romance languages, whereas the Jew appears as a doppelgänger of the German (Wolfenstein, 1922b, 437). Evidently, Wolfenstein postulates a difference between Germans and Jews. It should be noted that "Jewish essence" is necessarily a set of construed reifications and essentialisms, which are in turn perceived to somehow define the Jews' unique mode of being. Moreover, its creation was essential, because it enabled the construction of a narrative around fragmentary instances that would be labelled "Jewish history" (Hughes 2014, 15, 52). Indeed, the core of this "essence" was seldom defined unambiguously or universally: for instance, obeying Jewish law, Halakha, could hardly be regarded as a decisive factor in any modern and secular environment. Moreover, the term "Jewish essence" could equally well prove constraining when people with highly varied religious beliefs, political pursuits or esthetic preferences were set under its normative umbrella. Wolfenstein sought, at least in part, to unravel the rather strict frame erected from, for instance, Max Brod's views on "Jewish essence."

\footnotetext{
${ }^{3}$ Brod ascribed to each artist of Jewish origin a "Jewish essence," regardless of whether there was anything particularly "Jewish" in the artist's work. For further discussion, see Móricz 2008, 7-9.
} 
A radical change in the German intellectual climate occurred following the disaster of the First World War, and led to the emergence of debates concerning a "Jewish essence." Germany experienced a temporary spiritual revulsion against war and materialism; this atmosphere prompted expressionism to engage in a struggle for peace, world brotherhood and the dignity of humanity. For the numerous Jewish members of the movement, it was also, simultaneously, a striving to find one's place in the world. This identity-focused political quest concerned Jews beyond the sphere of the avant-garde, which helps to explain why universalism became one of the key characteristics of expressionism's ideas about "Jewish essence."

In the context of the avant-garde, Wolfenstein (1922b, 433) clearly states that a "Jewish essence" was notable in expressionism but not equally in dada. ${ }^{4}$ The expressionist "Jewish essence" should be seen in relation to the overall situation in Germany. Coinciding with expressionism a second movement arose, one which aimed at the intellectual, moral and political rebirth of the Jewish people. This movement introduced its own idea of "Jewish essence" against which artists such as Wolfenstein reflected their understanding of the term. The main figures behind this intellectualist aspiration were Martin Buber and Franz Rosenzweig. Buber turned to East European Jews (Ostjuden) for a "genuine" kind of "Jewish essence," though he himself was an assimilated German Jew, a Westjude (e.g., Aschheim 1982, 129-133). He appropriated pseudo-nationalistic strategies, suggesting that the character of a people would derive from its past, and that this narrated past is always held in higher esteem than the corrupted present. Rosenzweig fell for a similar nostalgia. He imagined a past in which the "Jewish essence" he sought to revive in the modern period existed in a full and authentic form. In fact, his incorruptible "Jewish essence" meant that anything he deemed detrimental derived from the Jews' attempts to look to the outside world for political solutions to their problems. Rosenzweig concluded that these attempts could not solve anything for the Jews, because non-Jewish solutions overlooked the fact that Jews were unlike others (Hughes 2014, 90-92). Not only did Rosenzweig establish "Jewish essence" as a constricting frame, he also advocated Jewish particularity.

Hence, the signification of "Jewish essence" was problematic for the assimilated Westjuden who were native speakers of German and who had never embraced the Jewish tradition in the same manner as the Yiddish-speaking Ostjuden. The case of expressionism and the traditional Ostjuden was also complicated: expressionism's stance vis-a-vis tradition was influenced by avant-garde ideals, which were secessionist in character. However, in the avant-garde such separations were seldom transparent and final. From the avant-garde's point of view, the debate over "Jewish essence" meant that German Jews needed to determine both how to modernize Judaism and how a "Jewish essence" would fit into this undertaking. Appropriately, the German-Jewish theatre critic Julius Bab (1880-1955) associated himself with the Westjuden when engaging in the debate. According to him, German Jews were rooted exclusively in German culture and expressed their Jewishness only insofar as they tended to become mediators rather than creators of "Germanness" (Deutschtum). Echoing Rosenzweig, Bab rationalized that "Jewish creative instincts" were repressed when under the dictates of a "foreign culture" (Bab 1912, 4-5). It becomes apparent that Bab is arguing for a Jewish particularity that does not intermingle with the special indigenous character of German culture. ${ }^{5}$

\footnotetext{
${ }^{4}$ In contrast to the expressionists, the dadaists tended to eschew subjects relating to religion, especially those that did so in an affirmative way. A unique exception to this was John Höxter's 1919 special issue of Der blutige Ernst (Bloody Earnest), themed "Der Jude" (The Jew). It was a reaction to the post-revolutionary anti-Semitism in Germany and did not seek to assert any mode of "Jewish essence."

${ }^{5}$ Another aspect to this stance is Ludwig Strauss's $(1998,448)$ interpretation of Bab's writings, which highlight assimilation. Strauss avers that Bab in fact believed in the existence of a Jewish race within the German people.
} 
Regardless of his isolationism, Bab did not regard the Ostjuden as a solution in the manner of Buber. He argued that German Jews could not solve their problems by simply attaching themselves to Eastern Jewry because their relationship to German culture was too deep and natural (Bab 1912, 3; Aschheim 1982, 118). Bab was against every kind of cultural retrogression, especially the kind he recognized in Buber's vision. As Steven Aschheim $(1982,118)$ noted, according to Bab the Ostjuden could be integrated into the European community, but to propose the opposite for German Jews was absurd and would sever their roots from that community. This is to say that Bab regarded the Westjuden as an integral part of a modernizing Europe and did not see how relinquishing modernization would be feasible or even possible.

Following Bab's arguments, the literary critic Gustav Krojanker reflected on the place of Jews in German culture and among the literati. ${ }^{6}$ Focusing on Bab's statement concerning the Jew's position as a cultural outsider, Krojanker formulated that the problem arose from Jewish authors not developing an "authentic" voice:

Von je ist [...]jüdisches Wesen als ein Komplex von nicht nur andersartigen, sondern vor allem minderwertigen und verderblichen Eigenschaften so laut und verletzend dargestellt worden, dass der Jude, der sich die Werte nicht setzt, sondern von aussen bezieht, es ängstlich vermeidet, Dingen nachzugehen, als deren Resultat er von vornherein den Beweis seiner Drittrangigkeit und die Rechtfertigung seines Ausgechlossenseins erwartet. (Krojanker 1922, 7.)

(As a complex of not only dissimilar, but rather particularly inferior and perishable properties, the Jewish essence has been illustrated loudly and hurtfully, [which has suggested] that the Jew, who does not set the values himself but rather applies ones from outside, avoids the anxious pursuit of things, as a result of which he awaits a priori proof of his third-ratedness and a vindication of his debarment.)

In Krojanker's view the Jewish author is a passive mediator unless he or she takes cultural background into account. Only in such cases can the full Jewish particularity be manifested, which would eventually shatter the preconception of the Jew's fundamental "foreignness." Krojanker's text is therefore a step towards a self-assertion of the Jewish author and, hence, the recognition of a "Jewish essence."

Although Krojanker describes the Jews' relation to society at large, he does not pinpoint the characteristics that render the avant-garde "Jewish." Concerning the concrete characteristics of a "Jewish essence," Bab argued that these were first and foremost thematological. He stated that the use of traditional biblical themes would give rise to a work of art with Jewish particularity which would manifest this essence (Bab 1918, 397-398). Indeed, biblical themes had been widely used even by expressionists (e.g., Paul Adler and Ernst Toller), but not exclusively by Jewish ones. In fact, the most common religious variant in German drama amalgamated Jewish and Christian elements (cf. Anderson 2011, 81-92).

Regardless of the intermingling of these elements, or perhaps because of it, Bab decided to attack the avant-garde and its pursuits of cultural renewal. He stated that one should look for "das wahre jüdische Wesen mehr in seinen zeitlos großen Manifesten als in zufälligen Erscheinungen einer oft sebr unmassgeblichen Gegenwart' [the true Jewish essence rather in its great timeless manifestations than in the random

\footnotetext{
${ }^{6}$ Krojanker edited an anthology entitled Juden in der deutschen Literatur (Jews in German literature, 1922), which collected essays about German-Jewish authors penned by Jewish writers. Avant-gardists such as Meir Wiener, Albert Ehrenstein and Wolfenstein were represented in the volume - even Buber contributed an essay.
} 
phenomena of an often very non-substantial presence] (Bab 1918, 401). For Bab, the avant-garde was only one of the many contemporary manifestations of a "Jewish essence." Neglecting the avant-garde's paralleling with modernization, and the artists still wishing to identify themselves as Jews, Bab defined the avant-garde and Jewishness as antithetical. Any potential "Jewish avant-garde" would thus be defined via tradition - ultimately an oxymoron. Backtracking to Wolfenstein's image of the bridge, in Bab's vision the Jew seems to stand on it somewhat reluctantly, his nostalgic gaze fixed on the old shore, in the very vein of Buber and Rosenzweig.

\section{Jewish essence in German-Jewish expressionism}

In Bab's view, contemporary phenomena were unsubstantial in relation to Jewish history and the necessary narrative that dovetails with it. Wolfenstein, for one, represented a perspective that was opposite to that of Bab. In relation to the debate on "Jewish essence," expressionism's stance vis-à-vis tradition was made clear through, among other things, the participation of Jewish artists in expressionism. Wolfenstein characterized the idea of "Jewish essence" as a manifestation of the Jewish mode of being in a heterogeneous social world. He saw the Jew as the penultimate contemporary bearer of the signs of transition (Zeichen des Übergangs), and noted quasi-theologically that, as "old Judaism" had no female deity, Jewishness was necessarily male in spirit, which becomes apparent through varied symptoms of "restlessness" (Wolfenstein 1922b, 428). Such ambiguous characterizations were unfamiliar to the more tradition-inclined Jews.

The expressionists' rather eccentric interpretations of Judaism and Jewishness evoked criticism in conservative circles. For instance, Rabbi Leopold Fuchs expressed concern over the lack of theological essentialism - that is, a complete lack of Jewish essence - in the expressionists' understanding of Judaism:

Schon streitet man weniger um das, was nicht zum Judentum gehört, um die Negation, als darum, was positiv Judentum sei. Schon hört man seltener das Wort: mein Judentum besteht darin, das ich ein guter Mensch bin. [...] ich bin doch ein guter Jude! [...] Man sagt nicht mehr: Ich bin kein rechter Jude, denn ich glaube nicht an Bibel und Talmud, Wunder, Schöpfung, Verbalinspiration, persönlichen Messias, [oder] Verpflichtung zum Religionsgebets. (Fuchs 1924, 1.)

(Already we argue less about what does not belong to Judaism, about the negation, than what positive Judaism is. Even more rarely one hears the word: my Judaism is that I am a good person. Therefore, I am a good Jew! One no longer says: I am not a real Jew, because I do not believe in the Bible and Talmud, miracles, creation, verbal inspiration, a personal Messiah, or commitment to religious prayer.)

Fuchs regards the avant-garde as a middlebrow exercise when considered from a religious point of view. The rabbi's lamentation illustrates how the avant-garde had transmuted elements of Judaism into forms that were unrecognizable to conservative Jews. He highlights the neglect of traditional Judaism in the avant-garde, without noting the fundamentally antithetical character of each.

The renewal of religion was indeed related to modernization in Wolfenstein's case. His conception of "Jewish essence" is unique in that he implies the avant-garde to be a Jewish phenomenon: the Jew on the bridge faces modernization, and the so-called new shore could be his - hence, a sort of conditional 
promise looms over Wolfenstein's reckoning. The condition is related to urbanization: Wolfenstein (1922c, 29) acknowledges that the avant-garde arises from urban culture, which ultimately precludes the Ostjuden. As the avant-garde was closely linked with modernization, it was also concerned with how accustomed the Jews were to modern metropolitan life. Such consideration is undoubtedly worthwhile on a microhistorical level, yet what does it reveal about the role of the artist and the works of art in relation to a "Jewish essence"?

On this topic, Brod's formulations of Jewish art are noteworthy. He mapped the delicate interrelations between self-consciousness, intentionality and artistic work, but ended up declaring that Jewish art necessitates "a miracle" in which consciously and unconsciously Jewish factors amalgamate (Brod 1922, 207-208). Wolfenstein, for one, circumvented Brod's esoteric tones by noting that artists were allowed to reflect in a special way on the question of identity. According to him, the author recognizes a difference between the reality of his life and the reality of his work, which is to say that being Jewish does not automatically render one's auvre Jewish (Wolfenstein 1922c, 11). As the identities of the Jew as a person and as a poet are distinct, Wolfenstein's take on "Jewish essence" avoids the all-embracing yet constrictive elements characteristic of Brod's definition.

For Wolfenstein (1922c, 36), the avant-garde contains something essentially Jewish, because "Der Jude ist der unklassische Dichter" [the Jew is the non-classical poet]. Even though some now-canonized German writers such as Heinrich Heine and Theodor Lessing were Jewish, Wolfenstein's definition situated the Jewish author as parallel to the avant-garde, and thus outside German classical tradition. Obviously, in Wolfenstein's view the identity prompted by the avant-garde could not derive from the Ostjuden (Jewish tradition) or from classicism (German tradition). Hence, the critical question is where the avant-gardist element in Wolfenstein's "Jewish essence" derived from.

The early history of expressionism provides an answer. In its formative stages, expressionism witnessed the involvement of several artists of Jewish origin who were essential in developing and transforming the new esthetics. For instance, Jakob van Hoddis, Georg Heym and Kurt Hiller launched the Neopathetic Cabaret in 1910, one of the most influential soirées of early expressionism in Berlin. In addition, in the 1910s the expressionist magazines Der Sturm and Die Aktion were headed by Jewish editors - Herwarth Walden and Franz Pfemfert, respectively. These magazines (especially Walden's) introduced avant-garde esthetics and movements to the German public, while also addressing (as did Pfemfert's magazine, in particular) a broad spectrum of issues of Jewish interest. ${ }^{7}$ The sort of modernized Jewishness envisioned in these magazines presented the cultural avant-garde as an organic part of the pursuit.

In short, the avant-garde provided an esthetic platform where the Jew would not be considered an imitator or outsider. Whereas Bab had reduced the Jews to mere mediators of German culture, Wolfenstein (1922b, 439) states that the Jews would bring about "eine frische Vermählung mit den Dingen nicht naturalistisch sondern mythisch" [a fresh marriage of things, which is not naturalistic but rather mythical]. In other words, the "Jewish essence" thus lies in one's relation to things, things which are not grasped in any straightforwardly realistic or rational manner. Therefore, Wolfenstein's idea of "Jewish essence" does not involve the use of biblical themes, which could be (and were) applied by non-Jews as well; rather, it concerns the particular ways of ordering one's perceptions and ideas. In the midst of modernization, such an emphasis is understandable: urban culture, technology and new means of communication provided a renewed sense of reality, a sense that art could not disregard.

Accordingly, Wolfenstein needed to consolidate "Jewish essence" and modernization with what "Jewish" meant to him.

\footnotetext{
${ }^{7}$ For a more detailed analysis, see Sjöberg 2016.
} 
Appropriately, Brod $(1918,2)$ marvelled that Wolfenstein had created a Jewish mode of linguistic expression "within the German language, as paradoxical as that sounds." Wolfenstein was keen on bridging the demarcated halves of the term "German-Jewish" through the avant-garde. He sought to construct an esthetic symbiosis between "German clarity" (rationalism) and Jewish intellectual spirituality (Geistigkeit) by means of a new art (Wolfenstein 1922c, 439). The introduction of the avantgarde as a unifying factor would require both Jews and Germans to disavow their vernacular, which they assumed to represent the world "realistically," and to adopt a new perspective, a new way of relating to phenomena. Wolfenstein's stance suggests that, for him, the experiential world of the individual had undergone a radical change through modernization and that poetic language should follow suit.

Indeed, the "neue Dichtung kennt diese Unzufriedenheit mit dem Worte, als eine schwere Wabrheit" [new poetry is familiar with this dissatisfaction with the words, as a severe truth] (Wolfenstein 1922c, 23). Conventional language is here regarded as a hindrance to modernization, and thus a new form of language is required. The avant-garde is suitable for this, as it includes both an analysis of the situation and the means to recover from it. Hence, through the successful renewal of language a linguistic comradeship can be envisioned. Accordingly, Wolfenstein (1993b [1934], 398) concludes that "Die Dichtung löst durch Bewabrung und Verneinung deutschen und jüdischen Wesens den Hass auf - in ibrer Sprache ist die Freundschaft vollbracht' [Poetry erases through preservation and unification the German and Jewish characters' [mutual] hatred - in their language friendship is accomplished]. Hereby the Jew would relinquish the role of doppelgänger.

To succeed, the new poetry should modulate any religious element regardless of whether it was acting under the rubric of a "Jewish essence." This is to say that Wolfenstein sought to reinvent Jewishness as independent of religious tradition. Therefore, the remaining characteristically "Jewish" element in avant-garde art is the numerous unexpected interrelations between things, phenomena and the observers. Such a mode of Jewishness is related to tradition only by virtue of an interpretative "method" - an avant-gardist hermeneutics of sorts - and not through historical narrative, religion or ethnicity. Wolfenstein's "Jewish essence" is not a categorizable essence as such but rather a mode of being that is manifested through its relation to the world.

\section{Wolfenstein's Poetics of Jewish Essence}

Even though Fuchs's comment may have been applicable to certain expressionists, it was not especially valid for Wolfenstein. He aimed at shifting away from history and tradition and towards the modern era, without fully relinquishing the element of faith in favor of straightforward secularism. Wolfenstein regarded the situation through a certain revolutionary ethos, whereby the "new man" of the avantgarde was also the "new Jew." Approaching the issue by acknowledging the conservative perspective of Fuchs, he noted that "wir in einer auch für das Judentum revolutionären Epoche leben" [we live in an epoch that is revolutionary also for Judaism], meaning that Judaism itself would need to be modernized (Wolfenstein 1993a [1936], 402).

Wolfenstein's most precise formulation of the mismatch between religion and the avant-garde identifies the former with a certain inertia: "Religionen sind da, um ₹u trösten, zu berubigen, das zackige Hiersein abzurunden, und für solche überirdische Ergänzung benötigen andere Menschen andere Gottheiten. Die Kunst aber will ein irdisches Gegenüber des Lebens [sein], sie will nicht versüssen, nicht beschönigen, nicht [...] einschläfern. Sie will aufregen, will fort bewegen" [Religions are there to comfort, to soothe, to round off the jagged being-here, and for those unearthly supplements needing other people other deities. But art wants to be an earthly opposite to life, it does not want to sweeten, to gloss over, to sleep. It wants to get upset, wants to 
move forward] (Wolfenstein 1922b, 433). Instead of postulating a transcendent realm, the avant-garde focuses on the immediate.

This obvious dissimilarity between religion and the avant-garde led to the rabbis' regressive point of view losing influence, especially with young artists who were feeling estranged from traditional Judaism. "Eine neue Religion kann uns nicht einfallen" [A new religion cannot invade us], as Wolfenstein (1993a [1936], 403) phrased it. His idea of modernization was not the one prompted by Haskalah; rather, it was a new path, one enabled by the still largely unexplored potential of the "new poetry." However, Wolfenstein was discussing religion, not faith as such. In this sense, his formulations seem to derive from a more basic form of belief. He states that "Ich spreche hier vom spirituell schwebenden Wesen des Juden und seinem neuen dichtertum" [I speak here of the spiritually suspended essence of the Jews and their new "poetness"] (Wolfenstein 1922b, 429). This spiritual suspension refers to a partially transcendent quality of the Jewish essence, which is not fully here in this world at the present moment. This further connotes messianic aims and an eventual full realization of the very essence in the future.

Consequently, Wolfenstein balances between the avant-garde and the more conservative stances in revising the "Jewish essence" according to contemporary requirements. Hence, he characterizes the significance of the avant-garde to contemporary Judaism as follows:

In den Knieen der Epoche wartet, nach dem ersten irren Falle, vielleicht ein großer Sprung. Auch der Jude wird eine neue Gestalt gewinnen. Sein Auftreten im Aufrruhr der Gegenwart, Leben, Tod und Dichtung, kündigt sie schon an. Sie wird nur noch entschiedener seine spirituelle Sendung zu erkennen geben. So aber wird sie nicht nur deshalb wirken, weil dies Wesen sich in ihr wie für die Ewigkeit verstärkt, sondern auch weil die Gestalt, die es trägt, an Eigenschaften, es zu tragen und es auszudrücken, wachsen wird. Viele wüschen sich neuen Boden. Herrlicher ist die Unabhängigkeit einer neuen jüdischen Gestalt. Der Boden kann verloren gehen, das Geschick kann sich wütend immer wiederholen, weil man es nicht erkennt, ewige Zerstreuung, - Jerusalem kann wieder zerstört werden: die schwebende Sendung nicht. Sie fühlt grenzenlos durch Länder hindurch die unverwehrte Welt, die Gott gehört und ihre Bewohner von ihm erlangt.

(Wolfenstein 1922b, 440.)

(The knees of our era, after a first mistaken fall, may be flexed for a great leap forward. And the Jew will acquire a new form as well: he will emerge as a distant figure amidst the uproar of the present - life, death, and literature have already proclaimed as much, making his spiritual mission that much more decisive and clear. Literature will play a decisive role not because the essence of Judaism will become spiritually stronger, but because the new forms it assumes will increase its expressive capabilities. Many now seek a new land. But the independence of new forms of Jewish literary expression is more splendid still. A land can be lost, and fate can furiously be repeated because it has not been understood, producing an eternal diaspora - Jerusalem can be destroyed once more: but Judaism's transcendent mission, never. This mission transcends every state, envisioning an open world that belongs to God, and that citizens of its various states receive from him. $)^{8}$

Wolfenstein depicts a "Jewish world of writing" where literature and Jewishness are inseparable. Literature will assume new forms from avant-garde esthetics, which will transform the preceding literary language and supplement its expressive capabilities. Moreover, literature is seen as the home of the "landless," nomadic Jew. By virtue of this formulation, Wolfenstein produces a vision that is among the most poignant versions of the avant-garde's utopian aim of unifying art and life. The Jews who would previously have identified themselves as belonging to a certain creed and tradition - via

${ }^{8}$ Translated by Hermann Levin Goldschmidt. 
Judaism's seminal texts, such as the Torah and Talmud - should now identify with the avant-garde. In other words, Wolfenstein saw the avant-garde as a textual homeland by virtue of which Jews could affirm their identity.

Appropriately, one of the new forms derived from the avant-garde was anti-realism. Wolfenstein (1922b, 439) notes that Jews did not take part in realist movements, and that the "jüngere Generation [der Juden] schlug geistige Richtungen ein, mit denen sein Wesen zusammentraf, um spirituelle Dichtung zu werden" [younger generation of Jews struck spiritual directions together, by which they met their essence, to arrive at spiritual poetry]. The preference for an abstract "space" over nations is summarized in Wolfenstein's rather ambiguous idea of Judaism's transcendent mission. Due to its abstract character, this mission is unbound and mobile, potentially manifesting itself wherever the Jew is.

The equation's inclusion of Germans in this particularly Jewish textual "homeland" seems incongruent. This is due to the limited temporal perspective, however, and the situation should be seen in terms of the idea of suspension. The arrival of the avant-garde meant that Jews were not limited to imitating German literature, and that the new literary means at their disposal enabled them to master the qualities of the language of their expression. In other words, they renewed the poetic repertoire of the German language. Evoking Benjamin's idea of the Angel of History, the language of poetry itself epitomizes the messianic anticipation: "Die Lyrik, an sich schon eine Kunstart des klingenden Untergangs der Gegenstände in der Form, - begegnet sich mit dem hereinbrechen Gefübl eines Weltuntergangs. [...] Aber im Gedicht gibt sich die Gefahr zugleich wie überwunden" [The poetry is in itself an art form of the sounding doom of items in the form met with the feeling of a doomsday closing in. But in the poem, the risk is as good as overcome] (Wolfenstein 1922a, 347). Wolfenstein envisions a modernization where the conventional relations between things are ruptured, severed and lost. Poetry mediates the chaotic state where language is ruptured and, simultaneously, overcomes this development by appropriating it as a poetic device. Reality changes and so will poetry, which embodies the future in its vanguard character.

In its Wolfensteinian sense, avant-garde poetry negotiates between two temporalities. Logically, the new literature is a manifestation of the "Jewish essence" in which Wolfenstein recognized both a present and a future. The present is characterized by this "Jewish essence," in other words, particularity. Yet he wrote illuminatingly that poetry bears a foretaste of the future: "In der Dichtung wie in einem Paradiese des Menschen wandelt Gott" [God walks in poetry like in a human paradise] (Wolfenstein 1922c, 46). ' In this messianic phrase, poetry is the artificial paradise where God roams - suggesting that the future envisaged by Wolfenstein would become available through literature. As noted, literature would be the Jews' home, which posits them in the vanguard of the messianic future.

Wolfenstein's postulation of the new shore underlines his focus on the aspect of becoming. Hence, his aim is a messianic one where literature holds the promise of eventual paradise. According to Wolfenstein, "die Kunst besteht in ibrer Gegenwart. Sie bedeutet bereits die Erfüllung, das Paradies (dem man nicht wortwörtlich zumarschieren kann)" [Art is made of its contemporariness. It already signifies fulfilment, the paradise (through which one literally cannot march)] (Wolfenstein 1922b, 433). Here the contemporariness of art denotes the avant-garde that, for its part, embodies a paradise that is presently abstract. Paradoxically, the promised paradise that one aspires to is thus already in the avant-garde, in which the "now" becomes highlighted.

Art is indeed the indicator of the future in the present. The two temporalities of Jewish essence are suspended in poetry, which Wolfenstein recognized as the earthly opposite to life. Life can be lived only in the present, so anything opposite to life denotes what exceeds the temporality that life occupies.

\footnotetext{
${ }^{9}$ Here Wolfenstein echoes the Kabbalistic thought that identifies the original text (Torah) with divinity. Hence, his avant-garde poetry would include the Jewish God, whose preferred residence, according to the lore, was a "house of words."
} 
Regarding the aspect of becoming, there is already a hint of the potential future in the present: "Der Jude ist [...] ein Mensch [...] der Zeitkunst: Ein Mensch des Werdens, des Ganges, der Zeit - raumlos" [The Jew is a person of contemporary art: A man of becoming, of passage, of time - spaceless] (Wolfenstein 1922c, 48). Characterized in such a manner, the Jew embodies the desire to move forward, futurospection, and thus becomes parallel with messianism and the avant-garde. In short, being a Jew means living in a state of constant messianic tension that involves anticipation of a better future.

Wolfenstein's latent adoption of Jewish messianism seems to be practical in terms of socio-historical ends. The apocalyptic tones of expressionist poetry are not in his focus as much as art is, in its functioning as a platform that produces a sense of solidarity between Germans and Jews. To this end, Wolfenstein revises the Jewish tradition, by incorporating modern elements, and puts it at the service of modernization amongst his Jewish peers.

\section{Coda}

The task Wolfenstein imagined for the avant-garde - the unification of two cultures - was enabled by new means of literary expression. His rationale was that the new grammatical and linguistic anomalies, being neither German nor Jewish in character, would provide untrodden ground for a unified GermanJewish culture, where such a term would be regarded as a symbiosis instead of an oxymoron. The avant-garde seemed to offer the possibility of building a new future together. Poetry, being composed of concepts and words, was indeed in a special position to unite the fractions, for it applied the medium of people's thoughts. Wolfenstein's statements suggest the utopian aspiration of changing perspectives and creating objectivity via poetry.

Bab and Wolfenstein grasped the meaning of the contemporary to Jewishness in opposite ways. Bab looks to what he postulates as the resplendent history of the Jews, the Tanakh, the Talmudic tradition, from Antiquity to exile and diaspora, and actualizes all of this in the current state of things, arguing for acknowledgement of these features in art. Wolfenstein, on the other hand, seeks to renew Jewishness in such a way that it is reborn and thereby united with German culture in a transnational modern era.

Wolfenstein was aware that solving the German-Jewish dilemma required stepping outside the Jewish cultural canon yet simultaneously striving towards a messianic future. Even though Wolfenstein excludes religion, it is present via textuality and the status of the (divine) word as the basis of the Jewish tradition. Appropriately, he ties together, in a single sentence, the religious textual tradition and the avant-garde: "Das Wort insbesondere, die Sprache, [ist] das Ausdrucksmittel der Kunst und zugleich des Lebens" [The word in particular, the language, is the expression of art and - at the same time - life] (Wolfenstein 1934, 213). The avant-garde is seen as an anticipator of the future in the present.

Yet there looms a dilemma in Wolfenstein's conception of Jewish essence. The new interrelatedness of things is noted as a trait that derives from Jewish tradition, but when appropriated into the sphere of the avant-garde, it did not relinquish this particularity. Regardless of Wolfenstein's outspoken efforts, in his usage the avant-garde becomes another denominator for Jewish particularity instead of the utopia of universalism. In a rather conventional fashion, Wolfenstein falls victim to providing a set of reifications and essentialisms: the Jew who resides in avant-garde textuality can hardly be regarded as an overarching goal with the aim of inviting Germans in. 


\section{Sources}

Anderson, Lisa Marie. German Expressionism and the Messianism of a Generation. Amsterdam: Rodopi, 2011.

Aschheim, Steven E. Brothers and Strangers: The East European Jew in German and German Jewish Consciousness, 1800-1923. Madison: University of Wisconsin Press, 1982.

Bab, Julius. "Der Anteil der Juden an der deutschen Dichtung der Gegenwart." Mitteilungen des Verbandes der jüdischen Jugendvereine Deutschlands 3.12 (1912): 3-9.

Bab, Julius. "Die Wiederkunft des biblischen Motivs im jüngsten deutschen Drama." Neue jüdische Monatshefte 3.17 (1918): 396-401.

Brod, Max. “'Die Freundschaft' von Alfred Wolfenstein.” Selbstwehr 11.6 (1918), 2.

Brod, Max. Heidentum, Christentum, Judentum. Ein Bekenntnisbuch. Teil 1. Berlin: Kurt Wolff, 1922.

Fuchs, Leon. “Expressionistisches Judentum.” Jüdisch-liberale Zeitung 4.4 (1924), 1-2.

Hughes, Aaron W. Rethinking Jewish Philosophy: Beyond Particularism and Universalism. New York: Oxford University Press, 2014

Krojanker, Gustav (ed.). Juden in der deutschen Literatur: Essays über zeitgenössische Schriftsteller. Berlin: WeltVerlag, 1922.

Móricz, Klára. Jewish Identities: Nationalism, Racism, and Utopianism in Twentieth-Century Music. Berkeley: University of California Press, 2008.

Sjöberg, Sami. "Jewish Communality in German Avant-Garde Magazines of the 1910s and 1920s." Orbis litterarum, forthcoming.

Strauss, Ludwig. "Ein Dokument der Assimilation." Gesammelte Werke 4: Dramen, Epen, vermischte Schriften. Göttingen: Wallstein Verlag, 1998, 448-452.

Wolfenstein, Alfred. "Das neue Dichtertum des Juden." Juden in der deutschen Literatur: Essays über zeitgenössische Schriftsteller. Berlin: Welt-Verlag, 1922a, 333-359.

Wolfenstein, Alfred. "Jüdisches Wesen und Dichtertum (Aus einer größeren Arbeit).” Der Jude 6.7 (1922b), 428-440.

Wolfenstein, Alfred. Jüdisches Wesen und neue Dichtertum. Berlin: Erich Weiss Verlag, 1922c.

Wolfenstein, Alfred: "Von der Dichtung des Juden." Der Morgen : Monatsschrift der Juden in Deutschland 9.5 (1934), 208-215.

Wolfenstein, Alfred. "Jüdische Haltung." Werke. Vermischte Schriften: Ästhetik, Literatur, Politik. Mainz: Hase and Koehler, 1993a. 400-404.

Wolfenstein, Alfred. "Vom deutschjüdischen Dichter der Gegenwart." Werke. Vermischte Schriften: Ästhetik, Literatur, Politik. Mainz: Hase and Koehler, 1993b. 394-398. 